\title{
Fasting Status Indicator
}

National Cancer Institute

\section{Source}

National Cancer Institute. Fasting Status Indicator. NCI Thesaurus. Code C93566.

Specifies whether the subject has abstained from food and possibly water for the prescribed amount of time. 